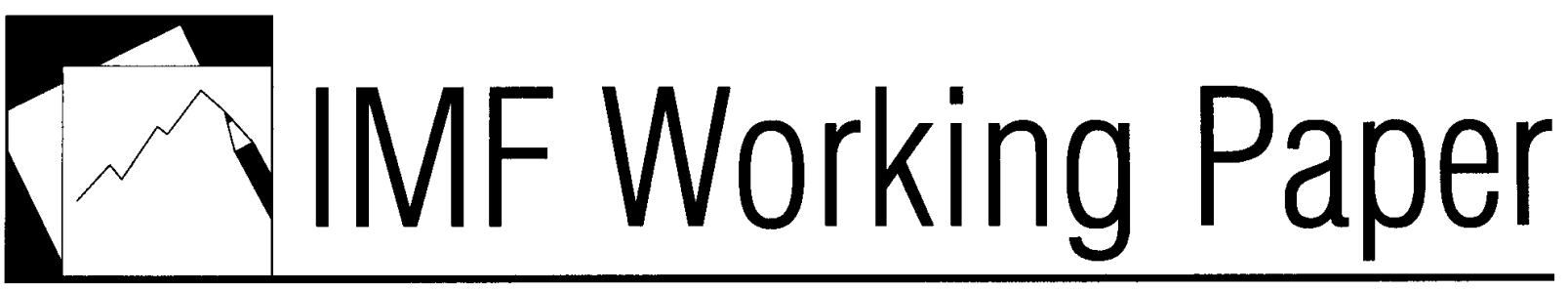

\title{
The Cyclicality of Fiscal Policies in the CEMAC Region
}

Gaston K. Mpatswe, Sampawende J.-A. Tapsoba, and Robert C. York 


\title{
IMF Working Paper
}

\author{
African Department
}

\section{The Cyclicality of Fiscal Policies in the CEMAC Region}

\author{
Prepared by Gaston K. Mpatswe, Sampawende J.-A. Tapsoba, and Robert C. York ${ }^{1}$ \\ Authorized for distribution by Paul Mathieu
}

August 2011

\begin{abstract}
This Working Paper should not be reported as representing the views of the IMF.

The views expressed in this Working Paper are those of the authors and do not necessarily represent those of the IMF or IMF policy. Working Papers describe research in progress by the authors and are published to elicit comments and to further debate.
\end{abstract}

This paper examines fiscal cyclicality in the CEMAC region during 1980-2008. The issue has attracted very little empirical interest but is important if fiscal policies are to play a role in mitigating external shocks that exacerbate economic cycles across the region. We assess whether fiscal policies across these six countries have been procyclical using panel data to elaborate our analysis. Like in other sub-Saharan countries, total public expenditure in the CEMAC is found to be strongly procyclical. This is most pronounced for public investment, which overreacts to output growth with elasticity above 1 . We further find that institutional weaknesses and poor governance partly explain this behavior. In contrast, the existence of an IMF-supported program can be a counterbalancing influence in attenuating this bias.

JEL Codes: E3, E6, H3.

Keywords: fiscal procyclicality, multilateral surveillance, monetary union

Author's E-Mail Address: gmpatswe@,imf.org: stapsoba@imf.org: ryork@imf.org

\footnotetext{
${ }^{1}$ This paper was prepared for a research project on the CEMAC region and will be included in a collection of papers on CEMAC's recent economic policies. It has benefited from insightful comments from Kossi Assimaidou, Olumuyiwa Adedeji, Victor Lledo, and Oral Williams. Any errors are, however, our own.
} 


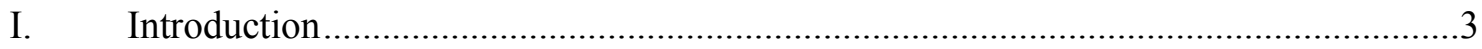

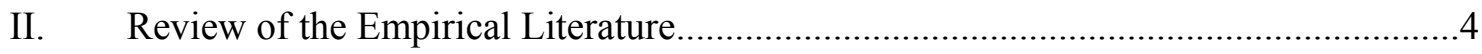

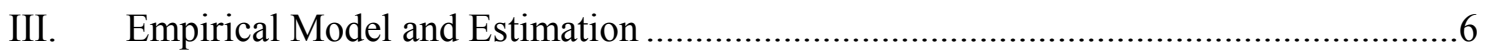

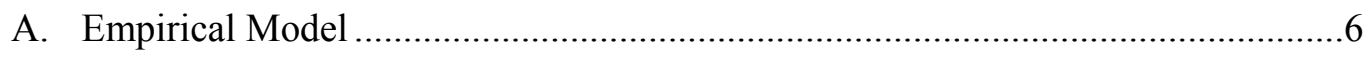

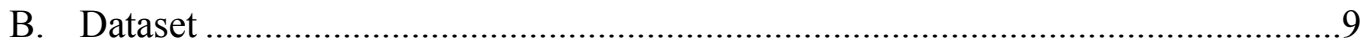

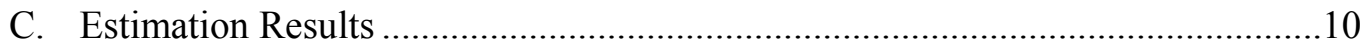

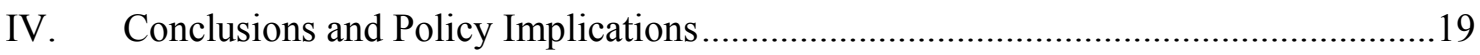

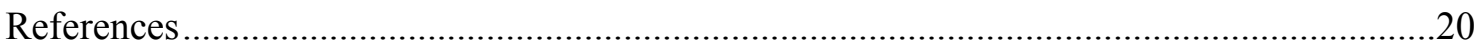

Box

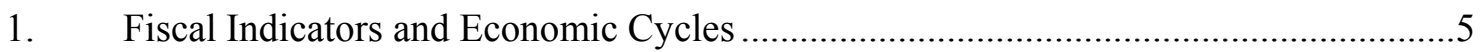

Tables

1. GMM Estimates of Cyclical Fiscal Policy in Sub-Saharan Africa, 1980-2008 ..........12

2. Fixed Effects Estimates of Cyclical Fiscal Policy in the CEMAC, 1980-2008 ..........13

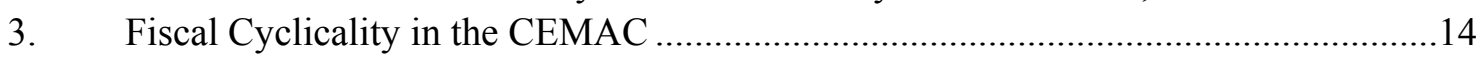

4. Determinants of Cyclical Fiscal Policy in the CEMAC, 1980-2008 .........................18

Figure

1. Time-Varying Cyclicality Coefficients across the CEMAC, 1980-2008 …...............15 


\section{INTRODUCTION}

To promote and sustain the CFA-pegged exchange rate regime and enhance regional economic integration, CEMAC member countries (Cameroon, Central African Republic, Chad, Equatorial Guinea, Gabon, and the Republic of Congo) are called upon to support a number of policy objectives. These policy objectives are translated into convergence criteria, which include achieving a nonnegative basic fiscal balance, maintaining total debt below 70 percent of GDP, nonaccumulation of domestic and external arrears, and annual inflation of no more than 3 percent. The adequacy and effectiveness of fiscal convergence in supporting the fixed exchange rate and integration is frequently called into question, because member countries have rarely observed it; mainly because the criterion is flawed in so far as it does not account for oil production in five of the six member countries and other factors (Iossifov and others, 2009).

The convergence criteria also fail to recognize an important dimension of fiscal policy, which concerns the possibility of procyclicality. The CEMAC Commission's narrow focus on a nonnegative fiscal balance could send misleading signals about fiscal policy performance in member countries because it does not prevent countries from spending windfall oil or commodity-export receipts as these prices rise. This goes against good fiscal management, which suggests that expenditure not be influenced by temporary changes in oil (or other commodity) prices. Of course, if the price shock is permanent then a structural shift in the expenditure envelope could be prudent and consistent with long-term sustainability. Like others (Iossifov and others, 2009) we would argue that fiscal surveillance in the region and individual countries in CEMAC should not rely solely on the current convergence criteria but also should include fiscal indicators that consider cyclical factors, the fiscal impulse, and the behavior of the non-oil aggregates and non-oil primary balance. Yet we are cognizant of the broader concerns over procyclical fiscal policies, which can exacerbate economic fluctuations, hamper growth, and have long-term welfare implications (IMF, 2005). Also, if expansionary fiscal policies in good times are not fully offset in bad times, they may lead to large fiscal deficits and a buildup of debt and the problems associated with it, including default.

The aim of this paper is to shed further light on the nature of fiscal policies across the CEMAC, and in particular, to assess whether there is procyclical bias - an important question that has attracted little empirical interest for the region. We use a panel data approach to address this question and we assess the cyclicality of fiscal policies of CEMAC countries during 1980-2008 against other countries in the sub region. We examine the potential driving factors behind fiscal policies across the CEMAC and extend the empirical literature by employing a time-varying coefficient model to look at procyclicality coefficients over time.

The paper is organized as follows. In Section II, we provide a review of the empirical literature devoted to the CEMAC and in Section III we lay out our empirical model and estimation. We draw some conclusions and policy implications in Section IV. Overall, our findings support most existing literature demonstrating that fiscal policies are strongly procyclical across the region and there is significant evidence of persistence. 


\section{REVIEW OF THE EMPIRICAL LITERATURE}

Only a few empirical studies have investigated the cyclicality of fiscal policies in CEMAC member countries. The few studies that do exist have followed the mainstream literature in focusing on co-movements of various indicators of fiscal policy and output cycles. While the various studies use different econometric techniques, the modeling strategy is generally similar. A fiscal reaction function of the following (generic) form is estimated

$$
g_{i, t}=\alpha+\gamma g_{i, t-1}+\beta y_{i, t}+X_{i, t}^{\prime} \delta+v_{i, t}
$$

where $i$ and $t$ represent country and period, respectively, $g_{i, t}$ and $y_{i, t}$ are respectively, indicators of fiscal policy (defined, for example, in terms of the fiscal balance as share of GDP or total government expenditure) and output cycles (which could be defined either as output gaps or growth rates), $X_{i, t}^{\prime}$ represents a vector of control variables; and $v_{i, t}$ captures fiscal shocks. The disturbance term $v_{i, t}$ can be decomposed into three orthogonal components: a country-specific fixed effect $\mu_{i}$; period random terms $u_{t}$; and an idiosyncratic fiscal shock $\xi_{i t}\left(v_{i, t}=n_{i}+u_{t}+\xi_{i t}\right)$. The cyclicality of fiscal policy is determined by looking at the sign and the size of the coefficient $\beta$. When the indicator of fiscal policy is expressed in terms of government expenditure procyclicality is assumed in the data if $\beta>0$, i.e., a cyclical upturn (downturn) is associated with an increase (decrease) in government spending; countercyclical if $\beta<0$; and acyclical if $\beta=0$. While a few authors examine the fiscal balance in equation (1), the majority of studies focus on the growth or level of public spending when testing for cyclicality, especially in low-income countries with limited data and oil-producing countries (Box 1).

Adedeji and Williams (2007) and Weigand (2004) are the only two papers that focus on CEMAC countries. Although their interests were not on investigating fiscal cyclicality directly, the issue of fiscal procyclicality is raised in the analysis but the conclusions are not clear cut. Rather than government spending as the dependent variable, Adedeji and Williams (2007) regress the basic fiscal balance on output, debt-to-GDP ratio, lagged-dependent variable, and other control variables. Their model is estimated using both fixed effects and the difference and system generalized method of moments estimators (GMM) on annual panel data for the six countries covering 1990-2006. They find that the coefficient on the lagged basic primary fiscal balance is positive and significant, suggesting a high degree of persistence in fiscal policy. Since current fiscal performance is strongly determined by the previous year, they conclude that exogenous shocks - in the absence of automatic stabilizers-would result in procyclical fiscal policies across the region. In a paper assessing the fiscal convergence criteria in CEMAC, Wiegand (2004) finds some contrary evidence. He computes the elasticity of the non-oil basic fiscal balance with respect to the CFA franc oil price over time to check whether procyclicality is a matter of a concern. On this basis, no significant procyclicality is found over the period 1994-2001. Weigand (2004) suggests that large short-term changes in the non-oil balances are more closely aligned with political events than with oil price movements. 


\section{Box 1. Fiscal Indicators and Economic Cycles}

A common method for determining whether a fiscal policy is expansionary or contractionary is to test comovements between changes in various summary indicators of the fiscal balance (often expressed in proportion to output) against cyclical changes in output. In this context, a counter cyclical fiscal policy is defined as running fiscal deficits in bad times and surplus in good times whereas procyclical fiscal policy is defined as running fiscal deficits or a surplus lower than what would otherwise have been achieved given the cycle of the economy, during good times.

Reinhart, Kaminsky, and Végh (2004) among others have questioned the accuracy of fiscal balance indicators in assessing the cyclicality of the fiscal stance, mainly on two grounds. First, the fiscal balance and other indicators like the revenue- and expenditure-to-GDP ratios reflect the outcomes of policy, and are affected only endogenously by the actions of policymakers. For this reason, the direction of comovements between these fiscal indicators and economic cycles might be ambiguous. Second, expressing fiscal variables as proportions of output could yield misleading results because the cyclical fiscal stance may be dominated by the cyclical behavior of output.

The assessment of the fiscal stance of oil-producing countries is a particular case in point: for example, an expansion through increased spending is masked by an improvement in the overall fiscal balance because of rising oil revenue. Moreover, although devised to correct such volatility from biasing policy analysis, the applicability of indicators of discretionary policy — including cyclically adjusted fiscal balances and the fiscal impulse - has limitations in the case of oil-exporting countries. These indicators rely heavily on estimates of output gaps and the elasticity of the budget to changes in output, which could raise specific issues for oil-producers because (i) they are subject to substantial and frequent (terms-of-trade) shocks, making it difficult to identify business cycles; and (ii) unlike most industrial non-oil producing countries where output fluctuates around a relatively stable trend, shocks to trend growth are the primary source of fluctuations in these countries, blurring the simple distinction between trend and cycle (Aguir and Gopinath, 2004).

Reinhart, Kaminsky, and Végh (2004) therefore advocate an approach that involves judging fiscal cyclicality by assessing the direction of co-movements between fiscal policy instruments - tax rates and government spending - and economic cycles. They propose that governments pursue:

- $\quad$ countercyclical fiscal policy when they lower (raise) spending and raise (lower) tax rates in good (bad) times, because, for example, a reduction of spending and raising of tax rates tends to stabilize the business cycle;

- $\quad$ procyclical fiscal policy when they raise (lower) spending and lower (raise) tax rates in good (bad) times; and

- $\quad$ acyclical fiscal policy when spending and tax rates remain constant over the economic cycle; a pattern that will neither reinforce nor stabilize the business cycle.

For many developing countries — including those in the CEMAC — the lack of comprehensive and systematic data on tax rates implies that government spending is probably the most reliable indicator for judging fiscal cyclicality.

Akitoby and others (2004) assess the short- and long-term behavior of government expenditure in 51 developing countries, including CEMAC members Cameroon and Congo during 1970-2002. Using an error-correction model, they find a positive short-term elasticity of government spending regarding output and conclude that fiscal policy is procyclical in more than half the countries, including the two CEMAC members. Also, they show that output and government spending for most countries and for at least one aggregate measure, are cointegrated; this implies a long-term relationship between them in line with "Wagner's Law".

Thorton (2008) uses ordinary least squares (OLS) to run individual-country regressions similar to equation (1) without the control variables on 37 sub-Saharan African (SSA) countries during 1960-2004. He finds that government consumption is, on average, extremely procyclical across the entire region; with government consumption responding more than 
proportionately to fluctuations in output in many cases (the mean across the region was 0.91 , with a standard deviation of 0.39 ). In particular, for CEMAC countries procyclicality is found to be significant and low for Chad and Gabon, and high for Congo and Equatorial Guinea.

Diallo (2008) investigates the impact of institutions on fiscal policy; he finds the existence of procyclical fiscal policies across the SSA region, but concludes this can be reversed by strong institutions. His empirical approach is slightly different than the generic equation (1) using instead a type of fiscal Taylor rule. He postulates that the fiscal stance can be captured by deviations of government spending from its trend; these deviations are itself driven by deviations in output captured in exogenous shocks, which Diallo proxies by movements in the terms-of-trade from their (Hodrick-Prescott filtered) trend. ${ }^{2}$ He uses system GMM on a panel of 47 countries, including all six CEMAC members during 1989-2002.

Lledó, Yackovlev, and Gadenne (2009) use several estimation methods (OLS, instrumental variables, and GMM) to estimate equation (1) for 174 countries, including 44 in SSA (and all six CEMAC members) during 1970-2008. They use several methods to account for the possible reverse causality between the growth in output and government spending. They find that $\beta$ is positive and statistically significant for all developing countries and more pronounced for those in SSA, although the procyclicality bias declined over time especially since the late 1990s.

Carmignani (2010) looks at correlation coefficients between filtered real government spending and filtered real GDP growth over 37 African countries, including three from the CEMAC (Cameroon, Chad, Gabon). He finds a statistically significant and positive relationship, which he concludes is evidence of procyclicality. CEMAC countries were classified among the procyclical countries.

Finally, using measures of the fiscal stance and fiscal impulse (both including and excluding oil revenue), Iossifov and others (2009) suggest that procyclicality was a prominent feature of fiscal policies in the CEMAC region, particularly after 2000, coinciding with the run-up in world oil prices over nearly a decade. The study noted that the ripple effects of terms-of-trade and real effective exchange rate shocks on the business cycles in the region are potentially magnified through fiscal policies. In their assessment, procyclical policies may exaggerate these effects whereas countercyclical policies could potentially mitigate them.

\section{EMPIRICAL MODEL AND ESTIMATION}

\section{A. Empirical Model}

To assess fiscal cyclicality, ideally we would like to estimate a fiscal reaction function whereby real government expenditure responds to change in real output cycles and other factors noted in the literature. A form of this reaction function is the Taylor-type rule without the inflation terms used by Diallo (2008). This reaction function assesses the direction and

\footnotetext{
${ }^{2}$ In Diallo (2008), terms-of-trade shocks are taken as an explanatory variable in place of the deviations of real GDP from its long-run trend. His formulation is built on the argument that shocks, such as terms-of-trade volatility - which are among the most important sources of shocks with which African countries are confronted - negatively affect the design and implementation of sound economic policies.
} 
level of co-movements between government spending and output deviations from their respective steady state trends

$$
\left(G_{i, t}-G_{i, t}^{*}\right)=\alpha+\gamma\left(G_{i, t-1}-G_{i, t-1}^{*}\right)+\beta\left(Y_{i, t}-Y_{i, t}^{*}\right)+X_{i, t}^{\prime} \delta+v_{i, t}
$$

where $\left(G_{i, t}-G_{i, t}^{*}\right)$ denotes the deviation of actual government spending from its long-run trend, $\left(Y_{i, t}-Y_{i, t}^{*}\right)$ the deviation of output (or real GDP) from its long-term trend, ${ }^{3} X_{i, t}$ and $v_{i, t}$ are defined as in equation (1). As above, the cyclicality of fiscal policy is determined by the sign and size of the coefficient on output $\beta$, which represents the short-run fiscal response to the economic cycle. Note that equation (2) is formulated in terms of co-movements between spending and economic cycles, and not in terms of fiscal balance indicators. For the reasons we outlined in Box 1, fiscal balance indicators may not be appropriate for judging cyclicality in low-income and oil-producing countries.

To estimate this reaction function, we would need adequate representations for the unobserved long-run values of government spending and output. One approach would be to use a filtering approach to estimate these values and then run the model in terms of spending and output gaps (e.g., Diallo, 2008). ${ }^{4}$ Another approach is to use a dynamic equation with the lagged values of these variables used as proxies for the long-run values and run the regression in first difference (e.g., Thorton, 2008)

$$
\Delta \log G_{i, t}=\alpha+\gamma \Delta \log G_{i, t-1}+\beta \Delta \log Y_{i, t}+X_{i, t}^{\prime} \delta+v_{i, t}
$$

where $\Delta$ is the first difference operator; $\log$ is the logarithm; coefficient $\beta$ would capture the short-term overall cyclical behavior of government spending without differentiating between discretionary fiscal actions from an automatic response to the economic cycle; and coefficient $\gamma$ would capture possible inertia effects or long-term mean reversion in government spending. This coefficient is expected to have a positive sign and be less than $1 .{ }^{6}$ Because automatic stabilizers are likely to be small in CEMAC countries, equation (3) is a reasonable approximation of discretionary fiscal policy. In addition, data to estimate equation (3) are easily available, thus avoiding the shortcomings of the filtering approach.

A consistent identification of $\beta$ requires addressing the potential endogeneity bias stemming from two factors: (i) the reverse causality between public expenditure and output because output is likely to be responsive to a fiscal stimulus; and (ii) the simultaneity bias because omitted variables, including country-specific factors are likely correlated with government spending. Following the work of Lledó, Yackovlev, and Gadenne (2009) and others, we address the endogeneity problem by estimating equation (3) with GMM methods (difference and systems) adapted for dynamic-panel estimation and fixed-effects estimators, which can

\footnotetext{
${ }^{3}$ The deviation terms could also be defined as spending gaps and output gaps, respectively, if related variables are expressed in logarithms or if the cyclical components are normalized onto the filtered trends.

${ }^{4}$ Box 1 highlights the difficulties of estimating output gaps, particularly for oil-exporting countries.

${ }^{5}$ Our methodology differs slightly from Thorton (2008), however, because it uses the panel dimension of the data.

${ }^{6}$ For a given time series process $k_{t}=\gamma k_{t-1}$ or equivalently $\Delta k_{t}=\gamma \Delta k_{t-1}$, mean reversion implies that $0<\gamma<$ 1. The series will either oscillate around the mean or drift away from the mean unless $|\gamma|<1$.
} 
control for country-specific factors. It should be noted that the lagged-dependent variable will be correlated with the regression error when using fixed effects. To determine the consistency of the estimated coefficients, we report the results with and without the lagged-dependent variable. We believe that endogeneity is less of a problem if the results do not change significantly. We use the two methods to improve on previous empirical work and to determine which leads to the most robust results. ${ }^{7}$ We include in the estimates, year-specific dummy variables to control for the CEMAC's covariant shocks to ensure that the identified fiscal behavior is specific to fiscal authorities only.

We carry out the estimation of equation (3) in two steps. In the first step, we focus solely on addressing the null hypothesis to determine whether fiscal policy is acyclical across the region $(\beta=0)$. We further allow this coefficient to be country-specific and time varying, as specified in equation in (4)

$$
\Delta \log G_{i t}=\alpha+\beta_{i t} * \Delta \log Y_{i t}+\vartheta_{i t}
$$

which is a modified form of equation (3), excluding the vector of control variables. Following Aghion and Marinescu (2009), we estimate equation (4) using local Gaussian-weighted ordinary least squares. This technique determines the time-varying cyclicality coefficient $\hat{\beta}_{i t}$ for country $i$ at year $t$, by using all observations and assigning greater weights to those observations closest to the reference year. This is achieved by giving a Gaussian-centered weight to the reference period. We also apply a ten-year rolling window approach to ensure that the cyclicality captured is a result of transitory discretionary fiscal policies. If $\tau$ denotes the length of the rolling window, then the error term $\vartheta_{i t}$ follows a normal distribution function: $N\left(0, \sigma^{2} / w_{t}(\tau)\right.$ with $w_{t}(\tau)=\frac{1}{\sigma \sqrt{(2 \pi})} \exp \left(-\frac{(\tau-t)^{2}}{2 \sigma^{2}}\right), \tau \in(t-5, t+4)$. As suggested in Aghion and Marinescu (2008), the smoothing parameter $\sigma$ is arbitrarily set to 5 because the results are qualitatively robust to slight changes of this parameter. ${ }^{8}$

In the second step, we pool the estimated time-varying cyclicality coefficients $\left(\hat{\beta}_{i t}\right)$ and regress them against the vector of control variables that are thought to be the main causes of cyclicality in developing countries (as noted in the literature above). This is represented in equation (5)

$$
\hat{\beta}_{i t}=\gamma+\sum\left(\delta^{k} * Z_{i, t}^{k}\right)+\eta_{i t}
$$

where $Z_{i t}^{k}$ denotes the explanatory variables and $\eta_{i t}$ is the classical error term encompassing a country-specific fixed effect and an idiosyncratic fiscal shock. The explanatory variables include political and institutional factors to capture rent seeking behavior that could drive

\footnotetext{
${ }^{7}$ The system and difference GMM is particularly adapted for dynamic panels, as it enables correction for any potential correlation between explanatory variables and the country-specific factors. It does not require external instruments and uses lagged variables to address the endogeneity bias. The difference GMM yields similar results to the system GMM while imposing fewer restrictions on the correlations between the instruments and the error term. The within fixed-effects estimator only controls for country-specific factors and mitigates the simultaneity bias. It does not address problems such as the reverse causality.

${ }^{8}$ The $\beta$ coefficients without control variables would be biased upward. However, estimating the coefficients without control variables allows us to explain fiscal procyclicality by the control variables.
} 
profligacy in public spending, weaknesses in governance (and corruption) and/or public financial management, election cycles, and financing constraints. ${ }^{9}$ In this paper, we proxy political institutional factors and governance through an election variable (measuring a political or electoral cycle), the Freedom House's civil and political liberty index (assessing the extent of democratization and the role of checks and balances on the fiscal authorities), and the World Bank's Country Policy and Institutional Assessment (CPIA) index (measuring the quality of policies and institutions); financing constraints are captured by aid-to-GDP ratios. Aid dependency is important and remains the main source of financing for developing countries when they are shut out of capital markets, or during economic downturns.

In addition to these usual factors, we test the potential influence of variables measuring fiscal space, which may affect a government's ability to conduct active spending policy. Fiscal space is defined as the room to maneuver, without jeopardizing fiscal sustainability. ${ }^{10}$ We also explore the role of IMF programs in creating such space. IMF-supported programs are viewed as policy anchors because they are generally accompanied by economic and structural reforms that could influence the conduct of fiscal policy. Accordingly, fiscal space is proxied by the current inflation rate, the lagged public debt-GDP-ratio and IMF-program status.

Given the heterogeneity across member countries and the prominence of oil in the CEMAC region (five of the six countries are oil exporters), we control for terms-of-trade shocks and the level of development using real GDP per capita. These factors could strongly influence the ability of the countries in the region to implement a countercyclical fiscal policy.

Finally, we introduce a dummy variable among the regressors to take account of the effects of the 1994 devaluation of the CFA franc, with the value 1 for the subsequent period. The assumption is that structural adjustments that accompanied the devaluation - as well as the subsequent adoption of regional convergence criteria - might have imposed some additional constraints on policy behavior of the fiscal authorities.

\section{B. Dataset}

The macroeconomic data for the six CEMAC countries and other SSA countries come from the IMF's World Economic Outlook (WEO) database and cover 1980-2008. Because of missing data, we end up with an unbalanced panel of 164 observations. From this database, we extract general-government total expenditure (including the breakdown into consumption and investment ${ }^{11}$ GDP deflator, GDP per capita, Consumer Price Index (CPI), trade shares, and terms-of-trade (TOT) of goods and services. Fiscal data and explanatory variables are

\footnotetext{
${ }^{9}$ For instance, Tornell and Lane (1999) have shown that if there are no institutional controls to limit policy discretion, the risk of overspending the windfall revenue during good times is high. Such profligacy tends to be ubiquitous in volatile environments (Talvi and Végh, 2005), corrupted regimes (Alesina, Campante, and Tabellini, 2008), and where weak institutions prevail with fewer checks on the executive (Diallo, 2008). Also, the lack of access to capital markets for developing countries triggers fiscal profligacy during downturns as concerns increase about government creditworthiness and fiscal sustainability (Gavin and Perotti, 1997).

${ }^{10}$ Heller (2005) defines fiscal space as the availability of budgetary room that allows a government to provide resources for a desired purpose without any prejudice to the sustainability of a government's financial position or the stability of the economy.

${ }^{11}$ Across the CEMAC, data on general government mainly reflects the central government.
} 
converted into real terms using the GDP deflator, when necessary, with 2000 as the base year. All indices are scaled to the year 2000 as well. We specifically compute TOT shocks by weighting the unexpected change of the TOT variable — using the Hodrik-Prescott filter with the smoothing parameter set to 100 - with trade shares. The intention is to model the exposure and vulnerability of each country to these shocks, especially those arising from the volatility of oil prices.

The other variables are taken from various sources. The election variable (taking the value 1 in an election year) is retrieved from the website African Elections Database (http://africanelections.tripod.com). The Freedom House index (ranging between 1 and 7) is a measure of the average of the civil liberty and political rights subindices and come from their website (http://www.freedomhouse.org). A higher value of the index is associated with less civil and political liberty. The CPIA score is from the World Bank and was rescaled between 0 and 1 to make different year's assessments comparable. A higher value of the score corresponds to better quality of institutions and policies. The IMF-program variable (taking the value 1 for countries under a program for a given year) and the public debt-to-GDP ratio are compiled from other IMF databases. ${ }^{12}$ Finally, aid to GDP ratios are drawn from OECD data.

\section{Estimation Results}

Table 1 reports the system and difference GMM estimates of the cyclicality of real public expenditure, consumption, and investment across SSA and the CEMAC region as specified in equation (4). ${ }^{13}$ The optimal lag structure of internal instruments in our regional dataset is four. Based on the classical appraisal criteria, the GMM results are internally consistent for the SSA estimates but not for the CEMAC subregion alone.

- For the SSA region as a whole, the results align with the empirical literature: there is strong evidence that fiscal policies are highly procyclical. The coefficient on output growth is close to 1 and is statistically significant at the 1 percent level. We find that procyclicality is also evident (and statistically significant at the 1 percent level) when considering public consumption and public investment as the dependent variable. ${ }^{14}$

- The behavior of public consumption is less procyclical than public investment, which has an estimated coefficient on output growth of close to 2 . This implies that investment is extremely responsive to economic cycles (i.e., a 1 percent increase in output growth leading to a 2 percent increase in the growth of public investment).

- When CEMAC countries are identified separately in the regression (through a dummy

\footnotetext{
12 In particular, debt data are taken from Abbas and others (2010).

${ }^{13}$ SSA includes 44 countries that are grouped in the IMF's African Department. It does not include the countries in North Africa.

${ }^{14}$ An IMF staff paper (IMF, 2010) concluded that low-income countries, including those in SSA, were able to use built-up fiscal space to conduct countercyclical fiscal policies during the recent global financial crisis. This difference in conclusions to this paper could reflect the data sample because the data for our paper runs only through 2008, just before the crisis.
} 
variable $\triangle \log Y * C E M A C)$, the results are similar. The corresponding coefficientwhich approximates the difference in fiscal cyclicality - is not statistically significant. This implies that CEMAC fiscal policies countries also exhibit procyclicality over our sample period and that public investment is highly reactive to the economic cycle. In other words, governments in the CEMAC region tend to increase (cut) public investment during good times (bad times) rather than other types of spending.

- $\quad$ Consistent with most of the empirical literature cited above, the inertia effect captured by the coefficient on the lagged fiscal policy variable is negative and statistically significant for public investment. From the spending side of the budget, this provides some evidence that the behavior of fiscal policies is consistent with long-term sustainability, although not for public investment, when controlling for CEMAC countries.

We also used the GMM for the CEMAC only, however, these result are not internally consistent. This is because the number of internal instruments far exceeds the number of countries; consequently the equation is over identified and the validity of using GMM (to address the endogenity bias) disappears. ${ }^{15}$ Instead, we rely on the fixed-effects estimates for the CEMAC countries, which are reported in Table 2 for real public expenditure, consumption, and public investment. These results mimic those from the GMM estimates over the entire SSA sample. We also display the results without the lagged-dependent variable to assess the extent of the possible correlation with the error component. The results remained qualitatively robust in these different specifications and we report on those including the lagged-dependent variable, to address the notion of fiscal sustainability (or more correctly, inertia).

- $\quad$ For the CEMAC, there is strong evidence of procyclicality because the coefficient on output growth is positive and statistically significant, with a magnitude similar to the SSA region (presented in Table 1). Once again, public investment is shown to be the most reactive to economic cycles with elasticity above 1 . Public consumption is also less responsive in line with wider sample results.

- $\quad$ The coefficient on the lagged-fiscal variable is negative, albeit weakly significant (at the 5 and 10 percent level) for total expenditure; it is also negative but not statistically significant for public investment. This reveals the possibility of inertia and variability in public spending but the effect could disappear over time (which is implied by the absolute value of the estimated coefficient of less than 1). York and Zhan (2009) reinforce the notion of persistence in government spending in considering the longterm sustainability of CEMAC oil-producing countries under a permanent-income framework. According to this study, public spending has driven the non-oil primary fiscal deficits too high and beyond levels consistent with their proven oil reserves and the relatively short time horizon of future production (i.e., long-term wealth).

\footnotetext{
${ }^{15}$ Simply by being numerous, instruments over fit the instrumented variables, failing to expunge their endogenous components and biasing the coefficient estimates toward those from nonincremental estimators. As a consequence, the over-identification test is biased toward the null hypothesis of the validity of instruments. We found that the probability of the Hansen J-statistic test equals 1 in all cases. Moreover, the first- and second-order autocorrelation tests are also biased towards the null hypothesis of the presence of autocorrelation.
} 
Table 1: GMM Estimates of Cyclical Fiscal Policy in Sub-Saharan Africa, 1980-2008

\begin{tabular}{|c|c|c|c|c|c|c|c|c|c|c|c|c|}
\hline \multirow{3}{*}{$\begin{array}{l}\text { Dependent variable } \\
\Delta \text { LogG }\end{array}$} & \multicolumn{6}{|c|}{ Difference-GMM } & \multicolumn{6}{|c|}{ System-GMM } \\
\hline & Total Public & Public & Public & Total Public & Public & Public & Total Public & Public & Public & Total Public & Public & Public \\
\hline & \multicolumn{2}{|c|}{ Expenditure Consumption } & Investment & \multicolumn{3}{|c|}{ Expenditure Consumption Investment } & \multicolumn{3}{|c|}{ Expenditure Consumption Investment } & \multicolumn{2}{|c|}{ Expenditure Consumption } & Investment \\
\hline$\Delta \log Y$ & $\begin{array}{r}0.893^{\star * *} \\
(0.244)\end{array}$ & $\begin{array}{c}0.444^{*} \\
(0.249)\end{array}$ & $\begin{array}{r}1.956^{\star * *} \\
(0.419)\end{array}$ & $\begin{array}{l}0.887^{\star *} \\
(0.372)\end{array}$ & $\begin{array}{r}0.372 \\
(0.369)\end{array}$ & $\begin{array}{r}2.102^{\star \star \star} \\
(0.484)\end{array}$ & $\begin{array}{r}0.950^{* \star *} \\
(0.238)\end{array}$ & $\begin{array}{l}0.516^{\star \star} \\
(0.239)\end{array}$ & $\begin{array}{r}1.925^{\star * *} \\
(0.437)\end{array}$ & $\begin{array}{l}0.954^{\star *} \\
(0.358)\end{array}$ & $\begin{array}{r}0.464 \\
(0.344)\end{array}$ & $\begin{array}{r}2.088^{\star * *} \\
(0.490)\end{array}$ \\
\hline$\triangle$ Log $Y^{\star}$ CEMAC & & & & $\begin{array}{r}0.024 \\
(0.427)\end{array}$ & $\begin{array}{r}0.212 \\
(0.414)\end{array}$ & $\begin{array}{r}-0.402 \\
(0.691)\end{array}$ & & & & $\begin{array}{r}-0.005 \\
(0.412)\end{array}$ & $\begin{array}{r}0.152 \\
(0.422)\end{array}$ & $\begin{array}{r}-0.470 \\
(0.782)\end{array}$ \\
\hline$\Delta \log (-1)$ & $\begin{array}{r}-0.058 \\
(0.044)\end{array}$ & $\begin{array}{r}-0.038 \\
(0.057)\end{array}$ & $\begin{array}{r}-0.137^{* * *} \\
(0.046)\end{array}$ & $\begin{array}{r}-0.059 \\
(0.043)\end{array}$ & $\begin{array}{r}-0.038 \\
(0.057)\end{array}$ & $\begin{array}{r}-0.138^{\star * *} \\
(0.047)\end{array}$ & $\begin{array}{l}-0.054 \\
(0.041)\end{array}$ & $\begin{array}{l}-0.038 \\
(0.058)\end{array}$ & $\begin{array}{r}-0.141^{* * *} \\
(0.046)\end{array}$ & $\begin{array}{r}-0.055 \\
(0.041)\end{array}$ & $\begin{array}{l}-0.039 \\
(0.057)\end{array}$ & $\begin{array}{r}-0.141^{* * *} \\
(0.046)\end{array}$ \\
\hline Constant & & & & & & & $\begin{array}{r}0.007 \\
(0.035)\end{array}$ & $\begin{array}{r}0.011 \\
(0.035)\end{array}$ & $\begin{array}{r}-0.011 \\
(0.049)\end{array}$ & $\begin{array}{r}0.007 \\
(0.037)\end{array}$ & $\begin{array}{r}0.013 \\
(0.037)\end{array}$ & $\begin{array}{r}-0.015 \\
(0.049)\end{array}$ \\
\hline Year dummies & Yes & Yes & Yes & Yes & Yes & Yes & Yes & Yes & Yes & Yes & Yes & Yes \\
\hline Observations & 905 & 921 & 921 & 905 & 921 & 921 & 943 & 959 & 959 & 943 & 959 & 959 \\
\hline Countries & 38 & 38 & 38 & 38 & 38 & 38 & 38 & 38 & 38 & 38 & 38 & 38 \\
\hline Instruments & 32 & 32 & 32 & 36 & 36 & 36 & 35 & 35 & 35 & 40 & 40 & 40 \\
\hline Hansen & 0.331 & 0.293 & 0.835 & 0.472 & 0.0843 & 0.736 & 0.601 & 0.395 & 0.626 & 0.772 & 0.123 & 0.783 \\
\hline $\mathrm{AR}(1)$ & 0.000 & 0.006 & 0.000 & 0.000 & 0.006 & 0.000 & 0.000 & 0.006 & 0.000 & 0.000 & 0.006 & 0.000 \\
\hline$A R(2)$ & 0.142 & 0.366 & 0.270 & 0.139 & 0.384 & 0.253 & 0.194 & 0.387 & 0.254 & 0.192 & 0.397 & 0.235 \\
\hline
\end{tabular}

Standard errors in parentheses, ${ }^{* * *} p<0.01,{ }^{* *} p<0.05,{ }^{*} p<0.1$

Source: Authors' estimates. 
Table 2: Fixed Effects Estimates of Cyclical Fiscal Policy in the CEMAC, 1980-2008

\begin{tabular}{|c|c|c|c|c|c|c|}
\hline \multirow[t]{2}{*}{$\begin{array}{l}\text { Dependent Variable: } \\
\Delta \text { LogG }\end{array}$} & $\begin{array}{l}\text { Total Public } \\
\text { Expenditure }\end{array}$ & $\begin{array}{c}\text { Public } \\
\text { Consumption }\end{array}$ & $\begin{array}{c}\text { Public } \\
\text { Investment }\end{array}$ & $\begin{array}{l}\text { Total Public } \\
\text { Expenditure }\end{array}$ & $\begin{array}{c}\text { Public } \\
\text { Consumption }\end{array}$ & $\begin{array}{c}\text { Public } \\
\text { Investment }\end{array}$ \\
\hline & \multicolumn{3}{|c|}{ With the Lagged Dependent Variable } & \multicolumn{3}{|c|}{ Without the Lagged Dependent Variable } \\
\hline$\Delta \log Y$ & $\begin{array}{r}0.932^{* * *} \\
(0.133)\end{array}$ & $\begin{array}{r}0.652^{\star * *} \\
(0.098)\end{array}$ & $\begin{array}{l}1.105^{\star *} \\
(0.356)\end{array}$ & $\begin{array}{r}0.918^{\star * *} \\
(0.121)\end{array}$ & $\begin{array}{r}0.674^{\star * *} \\
(0.111)\end{array}$ & $\begin{array}{l}1.092^{* *} \\
(0.308)\end{array}$ \\
\hline$\Delta \operatorname{LogG}(-1)$ & $\begin{array}{l}-0.200^{*} \\
(0.090)\end{array}$ & $\begin{array}{r}0.040 \\
(0.063)\end{array}$ & $\begin{array}{l}-0.151 \\
(0.145)\end{array}$ & & & \\
\hline Constant & $\begin{array}{r}-0.049 \\
(0.030)\end{array}$ & $\begin{array}{r}-0.011 \\
(0.065)\end{array}$ & $\begin{array}{r}-0.137 \\
(0.131)\end{array}$ & $\begin{array}{r}0.255^{\star * *} \\
(0.016)\end{array}$ & $\begin{array}{r}0.123 \\
(0.079)\end{array}$ & $\begin{array}{r}0.041 \\
(0.195)\end{array}$ \\
\hline Year dummies & Yes & Yes & Yes & Yes & Yes & Yes \\
\hline Observations & 155 & 164 & 157 & 161 & 170 & 163 \\
\hline Countries & 6 & 6 & 6 & 6 & 6 & 6 \\
\hline $\mathrm{R}^{2}$ & 0.333 & 0.298 & 0.154 & 0.322 & 0.298 & 0.138 \\
\hline
\end{tabular}

Standard errors in parentheses, ${ }^{* * *} p<0.01,{ }^{* *} p<0.05,{ }^{*} p<0.1$.

Source: Authors' estimates. 
We use equation (5) to shed light on the time-varying cyclicality coefficient by country and the OLS estimates for equation (4) to derive individual country coefficients. These coefficients are summarized in Table 3 and plotted in Figure 1. Both the coefficients ${ }^{16}$ and the figure show that CEMAC countries, except Chad, exhibit a high degree of procyclicality over a long period. There are, however, some significant cross-country differences in the cyclical behavior of fiscal policies. The cyclicality coefficient moves widely in the C.A.R., Congo, and Gabon, whereas Cameroon exhibits a sustained upward trend.

The result for Chad was unexpected and requires future investigation. Our estimates suggest that after 1994, all components of public spending tended to be countercyclical, while the empirical literature is ambiguous. For example, Carmignani (2010) estimates a negative but insignificant coefficient on government consumption during 1990-2007 (closer to our timeframe) while Thorton (2008) finds strong evidence of procyclicality for Chadian expenditure over a longer timeframe (1960-2003).

Table 3: Fiscal Cyclicality in the CEMAC

\begin{tabular}{lrrr}
\hline & $\begin{array}{c}\text { Total Public } \\
\text { Expenditure }\end{array}$ & $\begin{array}{c}\text { Public } \\
\text { Consumption }\end{array}$ & $\begin{array}{c}\text { Public } \\
\text { Investment }\end{array}$ \\
\hline Country estimates & & & \\
Cameroon & & & \\
CAR & $1.207^{* *}$ & $1.306^{* *}$ & $1.012^{* * *}$ \\
Chad & $2.039^{*}$ & 1.036 & $5.741^{* *}$ \\
Congo & -0.480 & -0.665 & -0.129 \\
Equatorial Guinea & 0.569 & 0.718 & 0.748 \\
Gabon & $0.861^{* * *}$ & $0.736^{* *}$ & $0.880^{* *}$ \\
Time-Varying estimates & $4.967^{\star * *}$ & $0.717^{* *}$ & $9.099^{* * *}$ \\
Mean & & & \\
Standard deviation & 1.879 & 1.039 & 2.863 \\
Maximum & 1.789 & 1.101 & 3.621 \\
Minimum & 6.126 & 4.555 & 10.842 \\
Number of times $\beta>0$ & -1.008 & -1.531 & -1.092 \\
Number of times $\beta>1$ & $148(92 \%)$ & $155(91 \%)$ & $138(85 \%)$ \\
Number of times $\beta<0$ & $83(52 \%)$ & $67(39 \%)$ & $103(63 \%)$ \\
Total & $13(8 \%)$ & $15(9 \%)$ & $25(15 \%)$ \\
\hline
\end{tabular}

${ }^{* * *} p<0.01,{ }^{* *} p<0.05,{ }^{*} p<0.1$. Percentage of total coefficients estimated in parenthesis.

${ }^{1}$ Estimates include lagged dependent variable in right-hand side variables. Source: Authors' estimates.

\footnotetext{
${ }^{16}$ Individual country coefficients should be viewed as indicative only given the limited time series and the use of OLS.
} 
Figure 1. Time-Varying Fiscal Cyclicality Coefficients in the CEMAC, 1980-2008
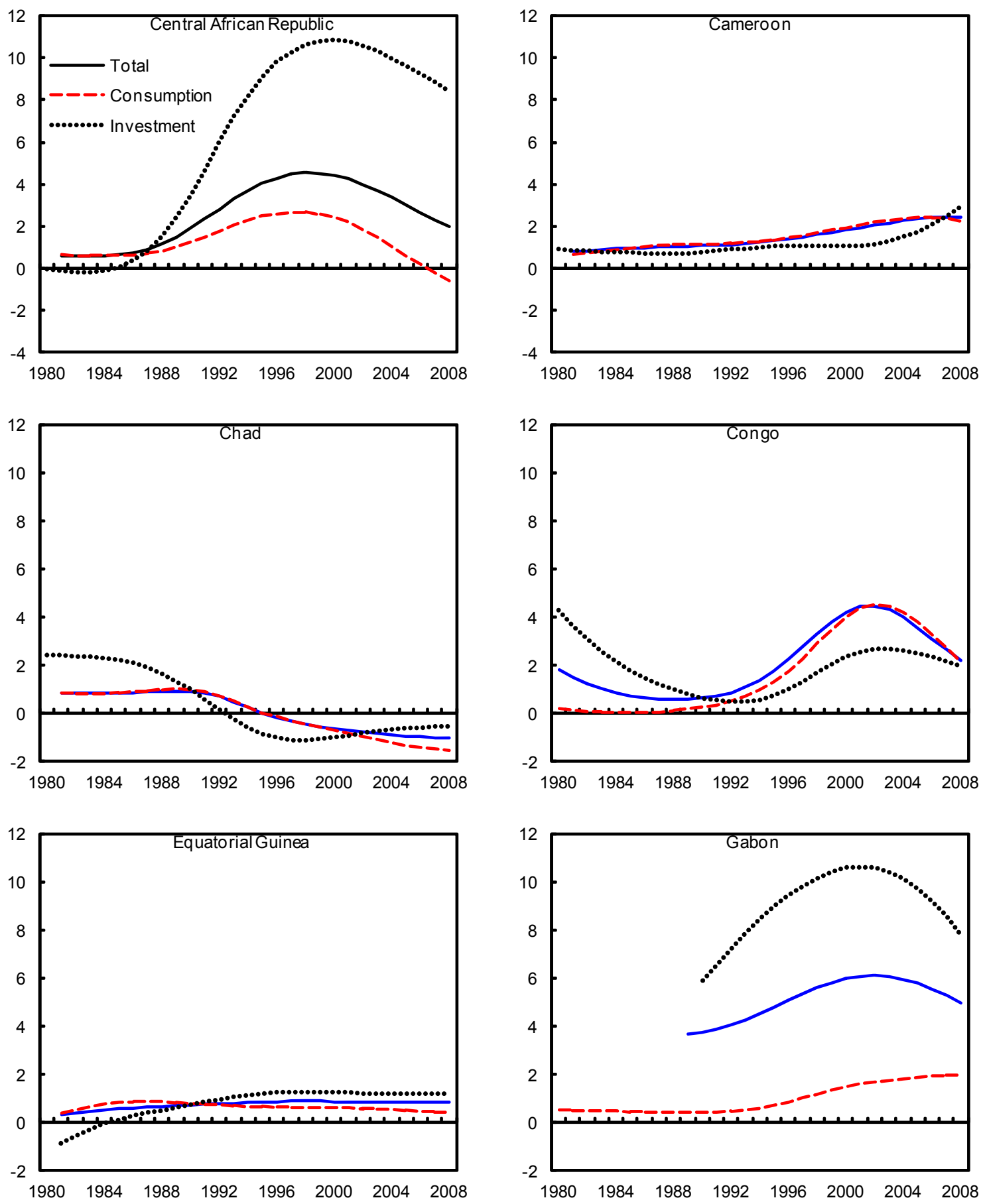

Source: Authors'estimates. 
Estimation of equation (5) also allows us to explore the factors driving the procyclicality of total government expenditure. In Table 4, we report the results of the regression of six sets of variables that have been shown in the empirical literature to influence the cyclicality of public spending: political and institutional factors, financing constraints, fiscal space, the level of economic development, external shocks, and structural change.

- $\quad$ Political and institutional factors: We anticipate ex ante, that elections would have a positive influence on the procyclicality of government spending and the quality of institutions would dampen profligacy, while political freedom would have an ambiguous effect. Our prior expectations are only partially borne out by the data. The quality of institutions play an important and quantitatively significant role in controlling total government expenditure and public investment in CEMAC countries, as does an improvement in political freedom. Election spending cycles are absent in the data, which is unexpected but not empirically significant.

- $\quad$ Financing constraints: The impact of financing constraint (proxied by the foreign aidto-GDP ratio) on fiscal cyclicality is ambiguous. On the one hand, high dependency on aid for government spending heightens fiscal procyclicality because external assistance empirically viewed as volatile, unpredictable, and overwhelmingly procyclical in many recipient countries (Pallage and Robe, 2001; Bulir and Hamann, 2008). Disbursements increase during expansion episodes and may stop suddenly in downturns, or during political instability and subsequent slow growth/recession. Meanwhile, foreign aid is likely to become the only available financing for government spending during a sharp decline in commodity exports and could help the conduct of countercyclical policy by relaxing the financing constraint. As in Thorton (2008), we find that aid drives the procyclicality of total expenditure, especially public investment. The coefficient on these fiscal variables is strongly positive and statistically significant. The claim that foreign aid is itself procyclical and triggers the profligacy of public spending is, therefore, evident across the CEMAC region.

- $\quad$ Fiscal space: We account for the notion of fiscal space through the debt-to-GDP ratio (lagged), inflation, and the existence of an IMF-supported program. Ex ante, we expect the existence of an IMF-supported program to dampen procyclicality, whereas lower inflation and debt may lead to the opposite effect. Perhaps not surprisingly, we find that the debt-to-GDP ratio and inflation do not have an empirically significant impact on public spending, when we control for the existence of an IMF-supported program. On the contrary, the data show that an IMF-supported program would encourage fiscal discipline and mitigate against procyclical behavior, with a statistically significant impact on total expenditure and public consumption but not significant on public investment.

- Level of economic development: Following the conclusions of most of the previous empirical studies that fiscal policies are less procyclical in wealthier countries (especially advanced countries), we would expect less procyclicality in richer CEMAC countries and a negative coefficient on GDP per capita. The data, however, reveals a positive and statistically significant relationship in the regression for total expenditure, 
suggesting that the wealthier CEMAC countries (notably Congo and Gabon in Figure 1) behave more procyclically. Perhaps this reflects their historical tendency to overspend oil windfall revenues, as noted in York and Zhan (2009).

- $\quad$ External (terms-of-trade) shocks: We expect that frequent and large terms-of-trade shocks stemming from oil price volatility would spur fiscal profligacy in CEMAC countries. In our analysis, we find that an expansion of public expenditure is heightened by unanticipated change in terms-of-trade shocks. This is inconsistent with the work of Talvi and Végh (2005), who postulate that under an unstable environment (i.e., with frequent shocks) and institutional weakness, it might be optimal for budgetary authorities in developing oil-producing countries to spend the windfall revenue during the good times, partly in response to demands from different political and social groups.

- $\quad$ Structural change: The impact of structural changes on the cyclicality of regional fiscal policies is ambiguous. We introduce a dummy variable for the period after the 1994 devaluation of the CFA franc, with a value of 1 in the post-1994 period. The dummy variable is not statistically significant as reported in Table 4. This finding is not consistent with suggestions from others (see for example, Lledó, Yackovlev, and Gadenne, 2009) that after 1996 and during the recent global financial crisis, public spending has tended to be countercyclical across the SSA countries more generally. 
Table 4: Determinants of Cyclical Fiscal Policy in the CEMAC, 1980-2008

\begin{tabular}{|c|c|c|c|c|c|c|}
\hline \multirow{2}{*}{$\begin{array}{l}\text { Estimator: Fixed Effects } \\
\text { Dependent Variable: } \beta \text {-Coefficient in } \\
\text { Equation (5) } \\
\text { Political and institutional factors }\end{array}$} & \multicolumn{2}{|c|}{$\begin{array}{l}\text { Total Public } \\
\text { Expenditure }\end{array}$} & \multicolumn{2}{|c|}{$\begin{array}{c}\text { Public } \\
\text { Consumption }\end{array}$} & \multicolumn{2}{|c|}{ Public Investment } \\
\hline & & & & & & \\
\hline Election & $\begin{array}{r}-0.263 \\
(0.192)\end{array}$ & $\begin{array}{r}-0.222 \\
(0.207)\end{array}$ & $\begin{array}{l}-0.197 \\
(0.286)\end{array}$ & $\begin{array}{l}-0.221 \\
(0.267)\end{array}$ & $\begin{array}{r}-0.243 \\
(0.208)\end{array}$ & $\begin{array}{l}-0.047 \\
(0.502)\end{array}$ \\
\hline Freedom-House index & $\begin{array}{r}-0.933^{* * *} \\
(0.353)\end{array}$ & $\begin{array}{r}-0.912^{* * *} \\
(0.312)\end{array}$ & $\begin{array}{l}-0.294 \\
(0.257)\end{array}$ & $\begin{array}{l}-0.284 \\
(0.278)\end{array}$ & $\begin{array}{r}-2.401^{* *} \\
(1.157)\end{array}$ & $\begin{array}{r}-2.344^{* *} \\
(1.010)\end{array}$ \\
\hline CPIA score & & $\begin{array}{r}-3.544^{* *} \\
(1.675)\end{array}$ & & $\begin{array}{l}-0.300 \\
(2.154)\end{array}$ & & $\begin{array}{r}-12.264^{* *} \\
(5.004)\end{array}$ \\
\hline \multicolumn{7}{|l|}{ Financing constraints } \\
\hline Aid-to-GDP ratio & $\begin{array}{l}2.782^{* *} \\
(1.168)\end{array}$ & $\begin{array}{l}4.526^{\star *} \\
(1.818)\end{array}$ & $\begin{array}{r}1.177 \\
(2.246)\end{array}$ & $\begin{array}{r}2.395 \\
(2.647)\end{array}$ & $\begin{array}{r}5.562 \\
(3.658)\end{array}$ & $\begin{array}{r}9.436^{* * *} \\
(3.124)\end{array}$ \\
\hline \multicolumn{7}{|l|}{ Fiscal space } \\
\hline Debt-to-GDP ratio (-1) & $\begin{array}{r}0.420 \\
(0.393)\end{array}$ & $\begin{array}{r}0.065 \\
(0.307)\end{array}$ & $\begin{array}{r}0.556 \\
(0.349)\end{array}$ & $\begin{array}{r}0.456 \\
(0.288)\end{array}$ & $\begin{array}{r}-0.391 \\
(1.150)\end{array}$ & $\begin{array}{l}-1.474 \\
(1.132)\end{array}$ \\
\hline Inflation & $\begin{array}{r}0.268 \\
(2.472)\end{array}$ & $\begin{array}{r}2.892 \\
(3.617)\end{array}$ & $\begin{array}{r}2.785 \\
(1.824)\end{array}$ & $\begin{array}{r}3.957 \\
(3.174)\end{array}$ & $\begin{array}{r}-3.004 \\
(6.236)\end{array}$ & $\begin{array}{r}4.157 \\
(6.855)\end{array}$ \\
\hline IMF program & & $\begin{array}{r}-1.006^{\star *} \\
(0.455)\end{array}$ & & $\begin{array}{l}-0.967^{*} \\
(0.561)\end{array}$ & & $\begin{array}{l}-1.699 \\
(1.112)\end{array}$ \\
\hline \multicolumn{7}{|l|}{ Level of development } \\
\hline Log Y per capita & $\begin{array}{l}0.924^{*} \\
(0.491)\end{array}$ & $\begin{array}{r}1.337^{* \star *} \\
(0.501)\end{array}$ & $\begin{array}{r}0.489 \\
(0.573)\end{array}$ & $\begin{array}{r}0.673 \\
(0.603)\end{array}$ & $\begin{array}{r}0.262 \\
(1.760)\end{array}$ & $\begin{array}{r}1.387 \\
(1.509)\end{array}$ \\
\hline \multicolumn{7}{|l|}{ External shocks } \\
\hline TOT shocks & $\begin{array}{l}0.278^{* *} \\
(0.138)\end{array}$ & $\begin{array}{r}0.415^{*} \\
(0.212)\end{array}$ & $\begin{array}{r}0.288 \\
(0.220)\end{array}$ & $\begin{array}{r}0.444 \\
(0.325)\end{array}$ & $\begin{array}{r}0.301 \\
(0.588)\end{array}$ & $\begin{array}{r}0.482 \\
(0.685)\end{array}$ \\
\hline \multicolumn{7}{|l|}{ Structural break } \\
\hline Dummy 1994 & $\begin{array}{r}0.063 \\
(0.836)\end{array}$ & $\begin{array}{r}0.334 \\
(0.979)\end{array}$ & $\begin{array}{r}-0.061 \\
(1.123)\end{array}$ & $\begin{array}{r}0.346 \\
(1.746)\end{array}$ & $\begin{array}{r}0.681 \\
(1.340)\end{array}$ & $\begin{array}{r}0.473 \\
(1.591)\end{array}$ \\
\hline Constant & $\begin{array}{r}-5.350 \\
(8.287)\end{array}$ & $\begin{array}{r}-8.410 \\
(7.609)\end{array}$ & $\begin{array}{l}-4.518 \\
(7.285)\end{array}$ & $\begin{array}{r}-6.324 \\
(7.368)\end{array}$ & $\begin{array}{r}13.226 \\
(26.173)\end{array}$ & $\begin{array}{r}6.130 \\
(21.839)\end{array}$ \\
\hline Year dummies & Yes & Yes & Yes & Yes & Yes & Yes \\
\hline Observations & 121 & 121 & 121 & 121 & 121 & 121 \\
\hline Countries & 6 & 6 & 6 & 6 & 6 & 6 \\
\hline $\mathrm{R}^{2}$ & 0.506 & 0.589 & 0.296 & 0.366 & 0.381 & 0.484 \\
\hline
\end{tabular}

Standard errors in parentheses, ${ }^{* * *} p<0.01,{ }^{* *} p<0.05,{ }^{*} p<0.1$.

Source: Authors' estimates. 


\section{Conclusions And Policy Implications}

Our empirical analysis confirms the results of previous studies addressing the behavior of government spending over the economic cycle. The panel data for the six CEMAC countries - Cameroon, Central African Republic, Chad, Congo, Equatorial Guinea, and Gabon-during 1980-2008 provide strong evidence of procyclicality. This result is consistent with public spending behavior observed in other studies across the sub-Saharan region more generally, although our analysis can provide further insights. The estimated cyclicality coefficients vary by country and over time, which is an interesting result that should be assessed more thoroughly to deepen the understanding of fiscal policies across these six countries.

For three of the six CEMAC countries, total public expenditure responds more than proportionately to fluctuations in output, with the reaction of the public-investment component extremely high. This has probably amplified economic cycles across the sub-region and inhibited (countercyclical) fiscal policies from playing an important role in mitigating a decline in output caused by external shocks (Iossifov and others, 2009). In a region buffeted by frequent external shocks stemming from oil-price volatility and other commodity prices, this is cause for concern. The highly responsive behavior of public investment to output fluctuations suggests weaknesses in public financial management across the CEMAC. The tendency to use windfall revenue to boost such spending when oil prices rise may not be appropriate, given the importance of maintaining tight expenditure control over publicinvestment programs, especially given capacity and institutional constraints in the subregion. This ramped up spending can easily be poor quality and wasted, with adverse implications for building the physical and human capital needed to generate long-term wealth in a region endowed with considerable natural resources but relatively high poverty.

Our analysis shows that institutional weaknesses and poor governance partly explain the procyclicality of CEMAC fiscal policies, as does foreign aid probably because of its own procyclical behavior. In contrast, the existence of an IMF-supported program could help provide a counterbalancing influence in attenuating — but not totally eliminating - this procyclical bias. We find that the level of debt is not a statistically significant driver of procyclicality across the CEMAC region. However, the coefficient on the lagged-dependent variable is negative implying some concern over the persistence and possible swings in government spending, which could have adverse consequences for the accumulation of public debt.

Finally, we note that the CEMAC Commission does not address the possibility of cyclicality in assessing its convergence criteria, which could send misleading signals about the fiscal policy performance in member countries. As we have shown, the focus on a nonnegative fiscal balance alone can accommodate procyclical behavior because it does not prevent members from spending windfall oil or commodity-export receipts as these prices rise. This goes against good fiscal management and fails to recognize the broader concerns about procyclical fiscal policies, including the potential for exacerbating economic volatility, and hindering growth, and the policies' long-term welfare implications. 


\section{References}

Adedeji, O., and O. Williams, 2007, "Fiscal Reaction Functions in the CFA Zone: An Analytical Perspective," IMF Working Paper WP/07/232

(Washington: International Monetary Fund).

Aghion, P., and I. Marinescu, 2008, "Cyclical Budgetary Policy and Economic Growth: What Do We Learn from OECD Panel Data?” NBER Macroeconomic Annual 2007, pp. 251-293.

Aguir, M., and G. Gopinath, 2004, "Emerging Market Business Cycles: The Cycle is the Trend," NBER Working Paper Series, No. 10734 (Cambridge, Massachusetts: National Bureau of Economic Research).

Akitoby, B., B. Clements, S. Gupta, and G. Inchauste, 2004, “The Cyclical and Long-Term Behavior of Government Expenditures in Developing Countries," IMF Working Paper WP/04/202 (Washington: International Monetary Fund).

Alesina, A., Campante, F. and G. Tabellini, 2008, "Why is Fiscal Policy often Procyclical?" Journal of the European Economic Association, 6(5), pp. 1006-1036.

Abbas, A., S. M., Belhocine, N., E. Ganainy, and M. Horton, 2010, “A Historical Public Debt Database,” IMF Working Paper WP/10/245 (Washington: International Monetary Fund).

Barnett, S., and R. Ossowski, 2003, "Operational Aspects of Fiscal Policy in Oil-Producing Countries," in Fiscal Policy Formulation and Implementation In Oil-Producing Countries ed. by J. Davis, R. Ossowski, and A. Fedelino (Washington: International Monetary Fund), pp. 45-81.

Bulir, A. and A. Hamann, 2008, "Volatility of Development Aid: From the Frying Pan into the Fire?" World Development, 36(10), pp. 2048-2066.

Carmignani, F., 2010, “Cyclical Fiscal Policy in Africa," Journal of Policy Modeling, Vol. 32, pp. 254-267.

Diallo, O., 2008, “Tortuous Road Toward Countercyclical Fiscal Policy: Lessons From Democratized sub-Saharan Africa," Journal of Policy Modeling, Vol. 31, pp. 36-50.

Gavin, M. and R. Perotti, 1997, "Fiscal Policy in Latin America," NBER Macroeconomics Annual, Vol. 12 (Cambridge: MIT Press), pp. 11-71.

Heller, P.S., 2005, “Understanding Fiscal Space,” IMF Policy Discussion Paper 05/4 (Washington: International Monetary Fund). 
International Monetary Fund, 2005, "Cyclicality of Fiscal Policy and Cyclically Adjusted Fiscal Balances," SM/05/393.

International Monetary Fund, 2010, "Emerging from the Global Crisis: Macroeconomic Challenges Facing Low-Income Countries," (Washington: International Monetary Fund)

Lledó, V., I. Yackovlev, and L. Gadenne, 2009, “Cyclical Patterns of Government Expenditures in Sub-Saharan Africa: Facts and Factors," IMF Working Paper WP/09/274 (Washington: International Monetary Fund).

Iossifov, P., N. Kinoshita, M. Takebe, R. York, and Z. Zhan, 2011, 2009, "Improving Surveillance Across the CEMAC Region”, IMF Working Paper WP/09/260 (Washington: International Monetary Fund).

Reinhart, C., G. Kaminsky, and C. Végh, 2004, "When it Rains it Pours: Procyclical Capital Flows and Macroeconomic Policies," NBER Macroeconomic Annual 2004 (Cambridge, Massachusetts: National Bureau of Economic Research).

Pallage, S., and M. Robe, 2001, "Foreign Aid and the Business Cycle," Review of International Economics, 9(4), pp. 641-672.

Talvi, E. and C. Végh, 2005, "Tax Base Variability and Procyclical Fiscal Policy in Developing Countries,” Journal of Development Economics, 78(1), pp. 156-190.

Thorton J., 2008, "Explaining Procyclical Fiscal Policy in African Countries", Journal of African Economies, 17(3), pp. 451-464.

Tornell, A. and P. Lane, 1999, "The Voracity Effect," American Economic Review, 89(1), pp. $22-46$.

Weigand, J. 2004, "Fiscal Surveillance in a Petro Zone: The Case of the CEMAC," IMF Working Paper WP/04/8 (Washington: International Monetary Fund).

York, R., and Z. Zhan, 2009, "Fiscal Sustainability and Vulnerability in Oil-Producing Sub-Saharan African Countries,” IMF Working Paper WP/09/174 (Washington: International Monetary Fund). 